\title{
Syntheses, characterization and structures of chromium group carbonyl complexes containing a multifunctional $\mathrm{Ph}_{2} \mathrm{P}\left(o-\mathrm{C}_{6} \mathrm{H}_{4}\right) \mathrm{CH}=\mathrm{N}\left(\mathrm{CH}_{2}\right)_{2}\left(o-\mathrm{C}_{6} \mathrm{H}_{4} \mathrm{~N}\right)$ ligand
}

\author{
Ching-Chao Yang ${ }^{\mathrm{a}}$, Wen-Yann Yeh ${ }^{\mathrm{a}, *}$, Gene-Hsiang Lee ${ }^{\mathrm{b}}$, Shie-Ming Peng ${ }^{\mathrm{b}}$ \\ a Department of Chemistry, National Sun Yat-Sen University, Kaohsiung 804, Taiwan \\ ${ }^{\mathrm{b}}$ Department of Chemistry, National Taiwan University, Taipei 106, Taiwan
}

Received 24 September 1999; received in revised form 15 November 1999; accepted 22 November 1999

\begin{abstract}
Reactions of the phosphine-imine-pyridine-containing ligand $\mathrm{Ph}_{2} \mathrm{P}\left(o-\mathrm{C}_{6} \mathrm{H}_{4}\right) \mathrm{CH}=\mathrm{N}\left(\mathrm{CH}_{2}\right)_{2}\left(o-\mathrm{C}_{6} \mathrm{H}_{4} \mathrm{~N}\right) \quad(\mathrm{PNN})$ with $\mathrm{M}(\mathrm{CO})_{3}(\mathrm{NCMe})_{3}\left(\mathrm{M}=\mathrm{Cr}\right.$, Mo, W) produce the tridentate complexes $f a c-\mathrm{M}(\mathrm{CO})_{3}\left(\eta^{3}-\mathrm{PNN}\right)$. On the other hand, treating $\mathrm{W}(\mathrm{CO})_{4}(\mathrm{NCMe})_{2}$ with PNN results in the bidentate complex $\mathrm{W}(\mathrm{CO})_{4}\left(\eta^{2}-\mathrm{PNN}\right)$, which converts to $f a c-\mathrm{W}(\mathrm{CO})_{3}\left(\eta^{3}-\mathrm{PNN}\right)$ upon heating, but no facial $\rightarrow$ meridional isomerism is evidenced. The new compounds have been characterized by elemental analysis and mass, IR, and NMR spectroscopy. The molecular structures of $\mathrm{W}(\mathrm{CO})_{4}\left(\eta^{2}-\mathrm{PNN}\right), f a c-\mathrm{W}(\mathrm{CO})_{3}\left(\eta^{3}-\mathrm{PNN}\right)$ and $f a c-$ $\mathrm{Mo}(\mathrm{CO})_{3}\left(\eta^{3}-\mathrm{PNN}\right)$ are determined by an X-ray diffraction study. (C) 2000 Elsevier Science S.A. All rights reserved.
\end{abstract}

Keywords: Chromium group; Multifunctional ligand

\section{Introduction}

The multifunctional compound $\mathrm{Ph}_{2} \mathrm{P}(o$ $\left.\mathrm{C}_{6} \mathrm{H}_{4}\right) \mathrm{CH}=\mathrm{N}\left(\mathrm{CH}_{2}\right)_{2}\left(o-\mathrm{C}_{6} \mathrm{H}_{4} \mathrm{~N}\right)(\mathrm{PNN})$, which contains a phosphine, an imine and a pyridyl electron-donating groups, was prepared by Lavery and Nelson from co-condensation of $\mathrm{Ph}_{2} \mathrm{P}\left(o-\mathrm{C}_{6} \mathrm{H}_{4}\right) \mathrm{C}(=\mathrm{O}) \mathrm{H}$ and $\mathrm{H}_{2} \mathrm{~N}\left(\mathrm{CH}_{2}\right)_{2}\left(o-\mathrm{C}_{6} \mathrm{H}_{4} \mathrm{~N}\right)$ [1]. Due to its flexible structure, this molecule can act either as a monodentate $\mathrm{P}$, a bidentate $\mathrm{P}-\mathrm{N}$ or a tridentate $\mathrm{P}-\mathrm{N}-\mathrm{N}$ ligand, which is applicable to the design of new catalytic reactions [2-5]. For instance, the hemilabile property of the pyridyl group has made the $[(\mathrm{PNN}) \mathrm{Pd}(\text { allyl })]^{+}$ complexes very active in allylic alkylation reactions [6].

We recently found the reactions of PNN with triosmium carbonyl clusters to afford complexes containing chelate and bridging PNN ligands as well as leading to $\mathrm{C}-\mathrm{H}$ and $\mathrm{C}-\mathrm{P}$ bond activation of the PNN ligand [7].

* Corresponding author. Fax: + 886-7-5253908.

E-mail address: wenyann@mail.nsysu.edu.tw (W.-Y. Yeh)
In the present research, we explore the reactions of PNN with mononuclear chromium group carbonyl complexes.

\section{Results and discussion}

\subsection{Syntheses}

Reactions of $\mathrm{M}(\mathrm{CO})_{3}(\mathrm{NCMe})_{3}$ with the PNN molecule at room temperature result in a facile substitution of the labile acetonitrile ligands to afford fac$\mathrm{M}(\mathrm{CO})_{3}\left(\eta^{3}-\mathrm{PNN}\right)$ in 52, 70 and $72 \%$ yields for $\mathrm{M}=\mathrm{Cr}$, Mo and $\mathrm{W}$, respectively (Eq. (1)). On the other hand, treating $\mathrm{W}(\mathrm{CO})_{4}(\mathrm{NCMe})_{2}$ with $\mathrm{PNN}$ produces the phosphine-imine bidentate complex $\mathrm{W}(\mathrm{CO})_{4}\left(\eta^{2}-\mathrm{PNN}\right)$, which transforms to $\mathrm{fac}$ $\mathrm{W}(\mathrm{CO})_{3}\left(\eta^{3}-\mathrm{PNN}\right)$ upon heating (Eq. (2)). The $\operatorname{Pd}(0)$, $\mathrm{Pd}(\mathrm{II})$ and $\mathrm{Pt}(\mathrm{II})$ complexes containing $\eta^{1}-\eta^{3}-\mathrm{PNN}$ ligands were prepared previously by Vrieze and coworkers [4,8], while the $\mathrm{Mo}(\mathrm{CO})_{4}$ complexes with the related $\mathrm{P}-\mathrm{N}$ and $\mathrm{P}-\mathrm{N}-\mathrm{N}-\mathrm{P}$ ligands were reported by Rauchfuss [9]. 

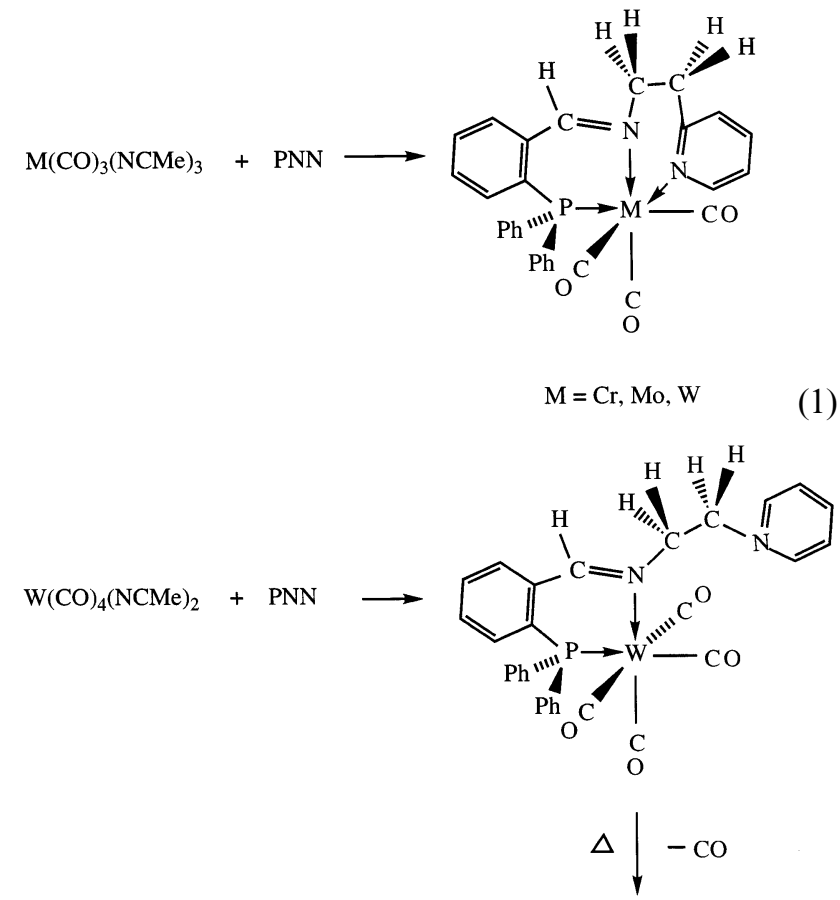

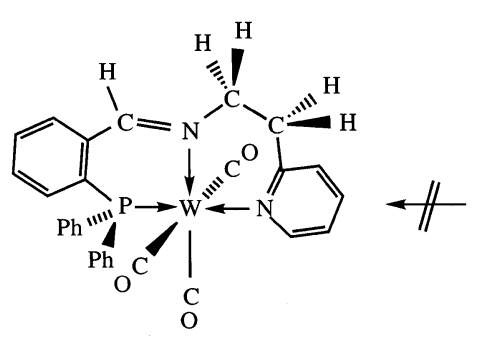

Mer-

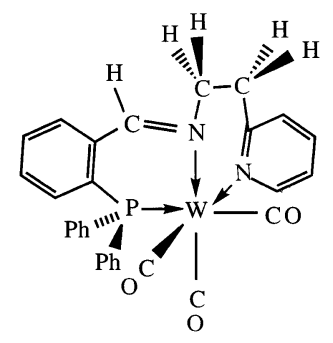

Fac-
Attempts to synthesize the tungsten poly( $\mathrm{PNN})$ complexes, such as $\mathrm{W}(\mathrm{CO})_{4}(\mathrm{PNN})_{2}, \mathrm{~W}(\mathrm{CO})_{3}(\mathrm{PNN})_{2}$ or $\mathrm{W}(\mathrm{CO})_{3}(\mathrm{PNN})_{3}$, have been unsuccessful. It was found that treating $\mathrm{W}(\mathrm{CO})_{3}(\mathrm{NCMe})_{3}$ with an excess amount of PNN, heating or photolysis of $\mathrm{W}(\mathrm{CO})_{4}\left(\eta^{2}-\mathrm{PNN}\right)$ in the presence of $\mathrm{PNN}$, or pyrolysis of $\mathrm{W}(\mathrm{CO})_{6}$ and $\mathrm{PNN}$ at high temperature led only to $f a c-\mathrm{W}(\mathrm{CO})_{3}\left(\eta^{3}-\mathrm{PNN}\right)$. Since both the $\mathrm{P}-\mathrm{N}$ and $\mathrm{N}-\mathrm{N}$ sets of the ligand can form a stable six-membered chelate ring upon coordination, it is probable that the chelate effect [10] is governing the products yielded.

The $\mathrm{d}^{6}$ metal tricarbonyl complexes $\mathrm{M}(\mathrm{CO})_{3} \mathrm{~L}_{3}$ exhibit facial ( $f a c)$ and meridional (mer) isomers. When $\mathrm{L}$ is a good $\sigma$ donor and poor $\pi$ acceptor relative to $\mathrm{CO}$, the $\mathrm{fac}$ isomer is expected to be more stable electronically to achieve stronger $\mathrm{M}-\mathrm{CO}$ back donation. On the other hand, the mer isomer is less sterically encumbered and is favored when $\mathrm{L}$ contains bulky groups $[11,12]$. For example, only fac-W $(\mathrm{CO})_{3}\left(\mathrm{PMe}_{3}\right)_{3}$ is existent while both $f a c-\mathrm{W}(\mathrm{CO})_{3}\left(\mathrm{PPh}_{3}\right)_{3}$ and mer$\mathrm{W}(\mathrm{CO})_{3}\left(\mathrm{PPh}_{3}\right)_{3}$ are present [13]. We were unable to convert $f a c-\mathrm{W}(\mathrm{CO})_{3}\left(\eta^{3}-\mathrm{PNN}\right)$ into mer-W(CO) $)_{3}\left(\eta^{3}-\right.$
PNN) thermally. Previous investigation on the transformation of $f a c-\mathrm{W}(\mathrm{CO})_{3}\left(\eta^{2}-\mathrm{dppf}\right)\left(\eta^{1}-\mathrm{dppm}\right)$ to $m e r-\mathrm{W}(\mathrm{CO})_{3}\left(\eta^{2}-\mathrm{dppm}\right)\left(\eta^{1}-\mathrm{dppf}\right)$ suggested a pathway through opening of the chelated diphosphine ligand [13]. Since the flexible PNN ligand reveals little ring constraint, the inaccessible $f a c \rightarrow m e r$ isomerism is probably due to the electronic effect.

\subsection{Characterization of new compounds}

Complexes $f a c-\mathrm{M}(\mathrm{CO})_{3}\left(\eta^{3}-\mathrm{PNN}\right)(\mathrm{M}=\mathrm{Cr}, \mathrm{Mo}, \mathrm{W})$ form air-stable, dark red crystals. Their FAB mass spectra exhibit molecular ion peaks at $m / z=530,574$ and 662 for ${ }^{52} \mathrm{Cr},{ }^{96} \mathrm{Mo}$ and ${ }^{184} \mathrm{~W}$, respectively, and fragments resulting from successive loss of three $\mathrm{CO}$ groups. The IR spectra in the carbonyl-stretching region for these complexes are similar, suggesting great resemblance of their structures.

The ${ }^{1} \mathrm{H}-\mathrm{NMR}$ spectrum of free $\mathrm{PNN}$ in $\mathrm{CDCl}_{3}$ presents a doublet resonance at $9.01 \mathrm{ppm}\left(J_{\mathrm{P}-\mathrm{H}}=5 \mathrm{~Hz}\right)$ for the $\mathrm{CH}=\mathrm{N}$ proton and two $2 \mathrm{H}$ triplets at 3.93 and 3.04 $\operatorname{ppm}\left(J_{\mathrm{H}-\mathrm{H}}=7 \mathrm{~Hz}\right)$ for the $\left(\mathrm{CH}_{2}\right)_{2}$ protons, while its ${ }^{31} \mathrm{P}\left\{{ }^{1} \mathrm{H}\right\}$-NMR spectrum shows a singlet at -13.08 $\mathrm{ppm}$ for the phosphine group. In the $f a c-\mathrm{M}(\mathrm{CO})_{3}\left(\eta^{3}-\right.$ $\mathrm{PNN}$ ) complexes, the phosphine ${ }^{31} \mathrm{P}$ resonances are shifted downfield to 50.94, 36.13 and $31.73 \mathrm{ppm}$ for $\mathrm{M}=\mathrm{Cr}$, Mo and $\mathrm{W}$, respectively, and the imine $\mathrm{CH}=\mathrm{N}$ ${ }^{1} \mathrm{H}$ resonances are shifted slightly to ca. $9.5 \mathrm{ppm}$. It has been noted that, for the metal phosphine complexes of a similar structure, one generally observes a high-field shift of the ${ }^{31} \mathrm{P}$ resonance as one descends in a given group [14]. Furthermore, the $\left(\mathrm{CH}_{2}\right)_{2}$ proton resonances are split into four $1 \mathrm{H}$ multiplets in the range $4.30-1.13$ ppm to indicate asymmetric coordination of the PNN ligand, leading to diastereotopic methylene groups.

$\mathrm{W}(\mathrm{CO})_{4}\left(\eta^{2}-\mathrm{PNN}\right)$ forms orange-red crystals. Its FAB mass spectrum displays a molecular ion peak at $m / z=690$ for ${ }^{184} \mathrm{~W}$, which is 28 more than that of fac- $\mathrm{W}(\mathrm{CO})_{3}\left(\eta^{3}-\mathrm{PNN}\right)$, and fragments corresponding to successive loss of four carbonyls. Apparently, either the $\mathrm{P}-\mathrm{N}$ or the $\mathrm{N}-\mathrm{N}$ set of PNN ligand is bonded to the W atom to satisfy the 18-electron rule. On the basis of the ${ }^{31} \mathrm{P}-\mathrm{NMR}$ spectrum, which displays a resonance at $24.19 \mathrm{ppm}$ with ${ }^{183} \mathrm{~W}$ satellites $\left({ }^{1} J_{\mathrm{W}-\mathrm{P}}=238 \mathrm{~Hz}\right)$, the $\mathrm{P}-\mathrm{N}$ coordination mode is preferred. The IR spectra of $\mathrm{W}(\mathrm{CO})_{4}\left(\eta^{2}-\mathrm{PNN}\right)$ and $f a c-\mathrm{W}(\mathrm{CO})_{3}\left(\eta^{3}-\mathrm{PNN}\right)$ in the carbonyl region are shown in Fig. 1; it appears that the absorptions are shifted to lower energy with increasing substitution, consistent with the stronger net donor capability of the PNN ligand compared with CO.

\subsection{Molecular structures}

Crystals of $\mathrm{W}(\mathrm{CO})_{4}\left(\eta^{2}-\mathrm{PNN}\right), f a c-\mathrm{W}(\mathrm{CO})_{3}\left(\eta^{3}-\mathrm{PNN}\right)$ and $f a c-\mathrm{Mo}(\mathrm{CO})_{3}\left(\eta^{3}-\mathrm{PNN}\right)$ contain an ordered array of discrete monomeric molecular units, which are mutu- 


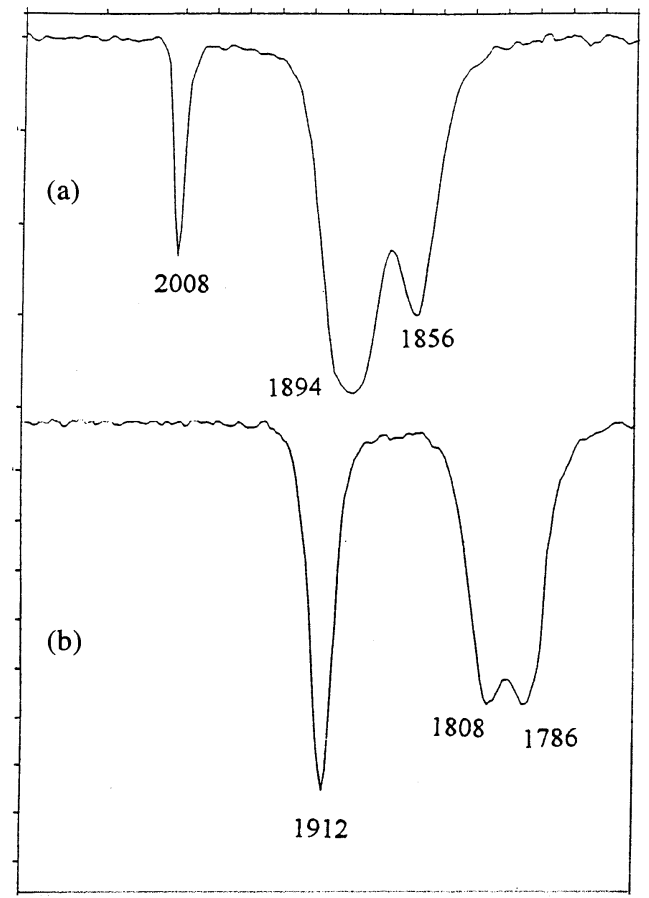

Fig. 1. IR spectra in the carbonyl region for (a) $\mathrm{W}(\mathrm{CO})_{4}\left(\eta^{2}-\mathrm{PNN}\right)$ and (b) $f a c-\mathrm{W}(\mathrm{CO})_{3}\left(\eta^{3}-\mathrm{PNN}\right)$ obtained in $\mathrm{CH}_{2} \mathrm{Cl}_{2}$ solvent.

ally separated by normal van der Waals distances. Their ORTEP diagrams are shown in Figs. 2-4. Selected bond distances and bond angles for $\mathrm{W}(\mathrm{CO})_{4}\left(\eta^{2}-\mathrm{PNN}\right)$ are given in Table 1 , and for $f a c-\mathrm{W}(\mathrm{CO})_{3}\left(\eta^{3}-\mathrm{PNN}\right)$ and $f a c-\mathrm{Mo}(\mathrm{CO})_{3}\left(\eta^{3}-\mathrm{PNN}\right)$ are collected in Table 2.

$\mathrm{W}(\mathrm{CO})_{4}\left(\eta^{2}-\mathrm{PNN}\right)$ is associated with four terminal carbonyls with the $\mathrm{W}-\mathrm{C}-\mathrm{O}$ angles in the range 174.7(4)-178.2(4) ${ }^{\circ}$. The W-CO distances are 2.024(4) $\AA$ to $\mathrm{C}(2)$ and 2.007(4) $\AA$ to $\mathrm{C}(4)$, while those distances trans to the phosphine and imine groups are slightly but significantly shorter, being $1.982(4) \AA$ to $\mathrm{C}(3)$ and

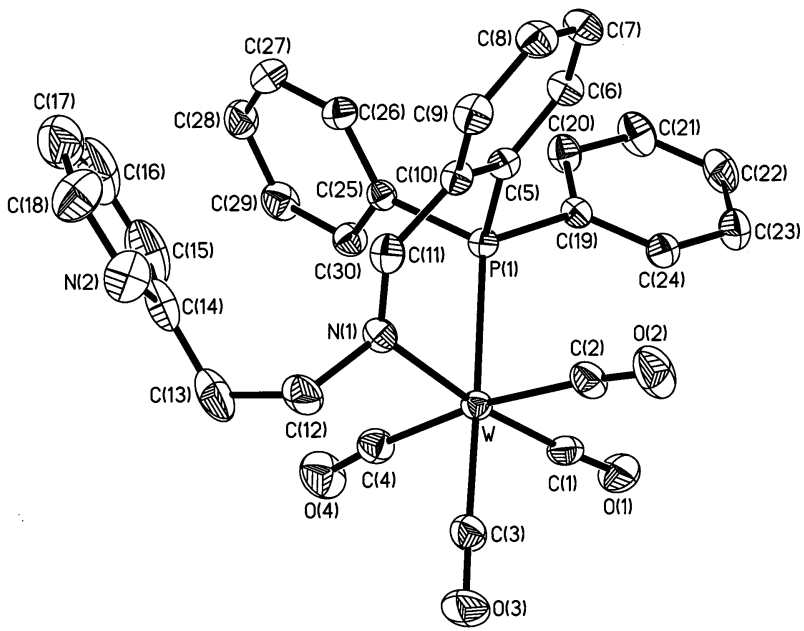

Fig. 2. Molecular structure of $\mathrm{W}(\mathrm{CO})_{4}\left(\eta^{2}-\mathrm{PNN}\right)$. Thermal ellipsoids are drawn at $30 \%$ probability. The hydrogen atoms have been artificially omitted for clarity.

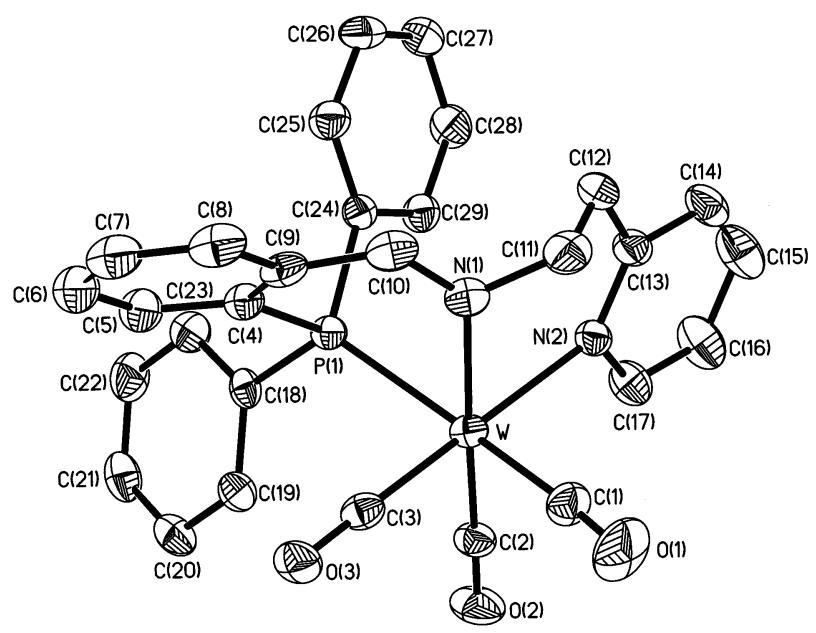

Fig. 3. Molecular structure of $f a c-W(C O)_{3}\left(\eta^{3}-\mathrm{PNN}\right)$. Thermal ellipsoids are drawn at $30 \%$ probability. The hydrogen atoms have been artificially omitted for clarity.

1.955(4) $\AA$ to $\mathrm{C}(1)$. Enhancement of $\mathrm{W} \rightarrow \mathrm{CO}$ back-donation for the latter two bondings is consistent with good $\sigma$ donor and poor $\pi$ acceptor of the phosphine (and imine) ligand relative to CO. The PNN ligand chelates the tungsten atom through the phosphineimine groups with the bite angle $\mathrm{P}(1)-\mathrm{W}-\mathrm{N}(1)=$ $80.74(2)^{\circ}$. The uncoordinated $\mathrm{C}(11)-\mathrm{N}(1)$ bond (1.275(5) $\AA$ ) retains a $\mathrm{C}=\mathrm{N}$ double-bond character.

The molecular structures of $f a c-\mathrm{W}(\mathrm{CO})_{3}\left(\eta^{3}-\mathrm{PNN}\right)$ and $f a c-\mathrm{Mo}(\mathrm{CO})_{3}\left(\eta^{3}-\mathrm{PNN}\right)$ are essentially identical, where the coordination about the central metal atom is a distorted octahedron with the PNN ligand capping a triangular face. Three terminal carbonyl ligands are linked to $\mathrm{W}$ and Mo atoms with the $\mathrm{M}-\mathrm{CO}$ distances in the range 1.927(5)-1.976(6) $\AA$ and the $\mathrm{M}-\mathrm{C}-\mathrm{O}$ angles in the range $175.3(6)-178.8(4)^{\circ}$. The $\mathrm{P}(1)-\mathrm{M}-\mathrm{N}(1)$, $\mathrm{P}(1)-\mathrm{M}-\mathrm{N}(2)$ and $\mathrm{N}(1)-\mathrm{M}-\mathrm{N}(2)$ angles are 79.1(1), 94.2(1) and $82.8(1)^{\circ}$ for $\mathrm{M}=\mathrm{W}$, and 78.5(1), 94.55(9)

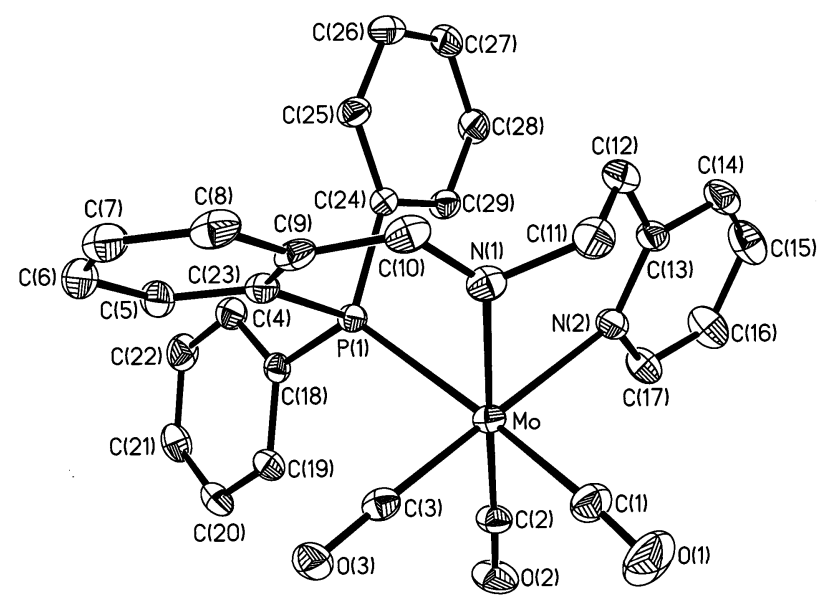

Fig. 4. Molecular structure of $f a c-\mathrm{Mo}(\mathrm{CO})_{3}\left(\eta^{3}-\mathrm{PNN}\right)$. Thermal ellipsoids are drawn at $30 \%$ probability. The hydrogen atoms have been artificially omitted for clarity. 
Table 1

Selected bond distances $(\AA)$ and bond angles $\left(^{\circ}\right)$ for $\mathrm{W}(\mathrm{CO})_{4}\left(\eta^{2}\right.$ PNN)

\begin{tabular}{lcll}
\hline $\begin{array}{l}\text { Bond distances } \\
\text { W-P(1) }\end{array}$ & $2.485(1)$ & $\mathrm{W}-\mathrm{N}(1)$ & $2.272(3)$ \\
$\mathrm{W}-\mathrm{C}(1)$ & $1.955(4)$ & $\mathrm{W}-\mathrm{C}(2)$ & $2.025(4)$ \\
$\mathrm{W}-\mathrm{C}(3)$ & $1.982(4)$ & $\mathrm{W}-\mathrm{C}(4)$ & $2.007(4)$ \\
$\mathrm{C}(1)-\mathrm{O}(1)$ & $1.163(4)$ & $\mathrm{C}(2)-\mathrm{O}(2)$ & $1.142(5)$ \\
$\mathrm{C}(3)-\mathrm{O}(3)$ & $1.150(5)$ & $\mathrm{C}(4)-\mathrm{O}(4)$ & $1.148(5)$ \\
$\mathrm{P}(1)-\mathrm{C}(5)$ & $1.826(3)$ & $\mathrm{C}(5)-\mathrm{C}(10)$ & $1.401(5)$ \\
$\mathrm{C}(10)-\mathrm{C}(11)$ & $1.475(5)$ & $\mathrm{C}(11)-\mathrm{N}(1)$ & $1.275(5)$ \\
$\mathrm{N}(1)-\mathrm{C}(12)$ & $1.492(4)$ & & \\
Bond angles & & & \\
$\mathrm{W}-\mathrm{C}(1)-\mathrm{O}(1)$ & $176.9(3)$ & $\mathrm{W}-\mathrm{C}(2)-\mathrm{O}(2)$ & $175.1(4)$ \\
$\mathrm{W}-\mathrm{C}(3)-\mathrm{O}(3)$ & $178.2(4)$ & $\mathrm{W}-\mathrm{C}(4)-\mathrm{O}(4)$ & $174.7(4)$ \\
$\mathrm{P}(1)-\mathrm{W}-\mathrm{N}(1)$ & $80.74(7)$ & $\mathrm{C}(1)-\mathrm{W}-\mathrm{N}(1)$ & $173.2(1)$ \\
$\mathrm{C}(3)-\mathrm{W}-\mathrm{P}(1)$ & $175.6(1)$ & $\mathrm{C}(2)-\mathrm{W}-\mathrm{C}(4)$ & $172.2(2)$ \\
$\mathrm{C}(11)-\mathrm{N}(1)-\mathrm{C}(12)$ & $113.9(3)$ & & \\
& & & \\
\hline
\end{tabular}

and $83.1(1)^{\circ}$ for $\mathrm{M}=$ Mo. The $\mathrm{P}(1), \mathrm{C}(4), \mathrm{C}(9), \mathrm{C}(10)$ and $\mathrm{N}(1)$ atoms are planar to within $\pm 0.1 \AA$ for both compounds. The $\mathrm{C}(10)-\mathrm{N}(1)$ double-bond distances are 1.281(7) and 1.276(6) $\AA$ for the $\mathrm{W}$ and Mo complexes,

Table 2

Selected bond distances $(\AA)$ and bond angles $\left(^{\circ}\right)$ for $f a c-\mathrm{M}(\mathrm{CO})_{3}\left(\eta^{3}-\right.$ $\mathrm{PNN})(\mathrm{M}=\mathrm{W}$ and $\mathrm{Mo})$

\begin{tabular}{|c|c|c|}
\hline & $\mathrm{M}=\mathrm{W}$ & $\mathrm{M}=\mathrm{Mo}$ \\
\hline \multicolumn{3}{|l|}{ Bond distances } \\
\hline $\mathrm{M}-\mathrm{P}(1)$ & $2.484(1)$ & $2.494(1)$ \\
\hline $\mathrm{M}-\mathrm{N}(1)$ & $2.228(4)$ & $2.243(4)$ \\
\hline $\mathrm{M}-\mathrm{N}(2)$ & $2.341(4)$ & $2.364(4)$ \\
\hline $\mathrm{M}-\mathrm{C}(1)$ & $1.976(6)$ & $1.970(5)$ \\
\hline $\mathrm{M}-\mathrm{C}(2)$ & $1.938(5)$ & $1.931(4)$ \\
\hline $\mathrm{M}-\mathrm{C}(3)$ & $1.940(5)$ & $1.927(5)$ \\
\hline $\mathrm{C}(1)-\mathrm{O}(1)$ & $1.144(6)$ & $1.150(6)$ \\
\hline $\mathrm{C}(2)-\mathrm{O}(2)$ & $1.171(6)$ & $1.166(5)$ \\
\hline $\mathrm{C}(3)-\mathrm{O}(3)$ & $1.163(6)$ & $1.168(5)$ \\
\hline $\mathrm{P}(1)-\mathrm{C}(4)$ & $1.837(5)$ & $1.834(4)$ \\
\hline $\mathrm{C}(4)-\mathrm{C}(9)$ & $1.410(7)$ & $1.403(6)$ \\
\hline$C(9)-C(10)$ & $1.456(8)$ & $1.454(7)$ \\
\hline $\mathrm{C}(10)-\mathrm{N}(1)$ & $1.281(7)$ & $1.276(6)$ \\
\hline $\mathrm{N}(1)-\mathrm{C}(11)$ & $1.461(7)$ & $1.475(6)$ \\
\hline $\mathrm{C}(11)-\mathrm{C}(12)$ & $1.508(8)$ & $1.503(7)$ \\
\hline$C(12)-C(13)$ & $1.492(8)$ & $1.496(7)$ \\
\hline $\mathrm{C}(13)-\mathrm{N}(2)$ & $1.345(6)$ & $1.351(5)$ \\
\hline \multicolumn{3}{|l|}{ Bond angles } \\
\hline $\mathrm{M}-\mathrm{C}(1)-\mathrm{O}(1)$ & $175.3(6)$ & $175.6(5)$ \\
\hline $\mathrm{M}-\mathrm{C}(2)-\mathrm{O}(2)$ & $178.8(4)$ & $178.2(4)$ \\
\hline $\mathrm{M}-\mathrm{C}(3)-\mathrm{O}(3)$ & $177.2(4)$ & $176.2(4)$ \\
\hline $\mathrm{P}(1)-\mathrm{M}-\mathrm{N}(1)$ & 79.1(1) & $78.5(1)$ \\
\hline $\mathrm{P}(1)-\mathrm{M}-\mathrm{N}(2)$ & $94.2(1)$ & $94.55(9)$ \\
\hline $\mathrm{N}(1)-\mathrm{M}-\mathrm{N}(2)$ & $82.8(1)$ & 83.1(1) \\
\hline $\mathrm{P}(1)-\mathrm{M}-\mathrm{C}(1)$ & $168.3(2)$ & $168.6(2)$ \\
\hline $\mathrm{C}(3)-\mathrm{M}-\mathrm{N}(2)$ & $177.8(2)$ & $177.9(2)$ \\
\hline $\mathrm{C}(2)-\mathrm{M}-\mathrm{N}(1)$ & $175.6(2)$ & $175.9(2)$ \\
\hline $\mathrm{C}(10)-\mathrm{N}(1)-\mathrm{C}(11)$ & $115.4(4)$ & $115.9(4)$ \\
\hline $\mathrm{N}(1)-\mathrm{C}(10)-\mathrm{C}(9)$ & $127.1(5)$ & $126.2(4)$ \\
\hline
\end{tabular}

respectively. We note that the $\mathrm{Mo}-\mathrm{CO}$ bonds are slightly shorter (av. $0.008 \AA$ ) than the W-CO bonds, while the $\mathrm{M}-\mathrm{P}(1), \mathrm{M}-\mathrm{N}(1)$ and $\mathrm{M}-\mathrm{N}(2)$ distances to the molybdenum atom are longer than those to the tungsten atom by $0.01-0.02 \AA$. Since the atomic sizes of Mo and $\mathrm{W}$ are comparable, this phenomenon might arise from electronic effects with different donor ability of the $\mathrm{CO}$ and PNN ligands and/or steric repulsions between the ligands.

\section{Experimental}

\subsection{General methods}

All manipulations were carried out under an atmosphere of purified dinitrogen with standard Schlenk techniques [15]. $\mathrm{Cr}(\mathrm{CO})_{6}, \mathrm{Mo}(\mathrm{CO})_{6}$ and $\mathrm{W}(\mathrm{CO})_{6}$ from Strem were used as received. Anhydrous $\mathrm{Me}_{3} \mathrm{NO}$ was obtained from $\mathrm{Me}_{3} \mathrm{NO} \cdot 2 \mathrm{H}_{2} \mathrm{O}$ (Aldrich) by sublimation under vacuum twice. $\mathrm{Ph}_{2} \mathrm{P}\left(o-\mathrm{C}_{6} \mathrm{H}_{4}\right) \mathrm{CH}=\mathrm{N}\left(\mathrm{CH}_{2}\right)_{2}(o$ $\left.\mathrm{C}_{6} \mathrm{H}_{4} \mathrm{~N}\right)$ was synthesized from condensation of $\mathrm{Ph}_{2} \mathrm{P}(o$ $\left.\mathrm{C}_{6} \mathrm{H}_{4}\right) \mathrm{C}(=\mathrm{O}) \mathrm{H}$ and $\mathrm{NH}_{2}\left(\mathrm{CH}_{2}\right)_{2}\left(o-\mathrm{C}_{6} \mathrm{H}_{4} \mathrm{~N}\right)$ (Aldrich) as described in the literature [1]. Solvents were dried over appropriate reagents under dinitrogen and distilled immediately before use [16]. Infrared spectra were recorded with a $0.1 \mathrm{~mm}$-path $\mathrm{CaF}_{2}$ solution cell on a Hitachi I-2001 IR spectrometer. ${ }^{1} \mathrm{H}-$ and ${ }^{31} \mathrm{P}-\mathrm{NMR}$ spectra were obtained on a Varian VXR-300 spectrometer at 300 and $121.4 \mathrm{MHz}$, respectively. Fast-atombombardment (FAB) mass spectra were recorded by using a VG Blotch-5022 mass spectrometer. Elemental analyses were performed at the National Science Council Regional Instrumentation Center at National Chung-Hsing University, Taichung, Taiwan.

\subsection{Synthesis of $\mathrm{fac}-\mathrm{Cr}(\mathrm{CO})_{3}\left(\eta^{3}-\mathrm{PNN}\right)$}

A $50 \mathrm{ml}$ Schlenk flask was equipped with a magnetic stir bar and a reflux condenser connected to an oil bubbler. $\mathrm{Cr}(\mathrm{CO})_{6}(101 \mathrm{mg}, 0.45 \mathrm{mmol})$ and acetonitrile $(15 \mathrm{ml})$ were introduced into the flask under dinitrogen, and the solution was heated to reflux for $72 \mathrm{~h}$, at which point the IR spectrum indicated $\mathrm{Cr}(\mathrm{CO})_{6}$ was completely transformed to $\mathrm{Cr}(\mathrm{CO})_{3}(\mathrm{NCMe})_{3}$. The acetonitrile solvent was then removed under vacuum. A solution of PNN (181 $\mathrm{mg}, 0.45 \mathrm{mmol})$ in dichloromethane $(10 \mathrm{ml})$ was added to the flask by a syringe and the reaction mixture was stirred at ambient temperature for $1 \mathrm{~h}$, resulting a solution color change from bright yellow to deep red. The solution was then dried under vacuum, and the crude product was crystallized from dichloromethane-hexane to afford dark red crystals of $f a c-C r(C O)_{3}\left(\eta^{3}-\mathrm{PNN}\right)(124 \mathrm{mg}, 0.23 \mathrm{mmol}$, $52 \%)$. IR $\left(\mathrm{CH}_{2} \mathrm{Cl}_{2}, v_{\mathrm{CO}}\right): 1914 \mathrm{~s}, 1810 \mathrm{~s}, 1788 \mathrm{~s} \mathrm{~cm}^{-1}$. 
${ }^{1} \mathrm{H}-\mathrm{NMR}\left(\mathrm{C}_{6} \mathrm{D}_{6}, 20^{\circ} \mathrm{C}\right): 9.56(\mathrm{~d}, \mathrm{CH}=\mathrm{N}), \quad 8.07-5.90$ (m, Ph, Py), $4.30(\mathrm{~m}, 1 \mathrm{H}), 2,95(\mathrm{~m}, 1 \mathrm{H}), 2.10(\mathrm{~m}, 1 \mathrm{H})$, $1.13\left(\mathrm{~m}, 1 \mathrm{H}, \mathrm{CH}_{2}\right)$ ppm. ${ }^{31} \mathrm{P}\left\{{ }^{1} \mathrm{H}\right\}-\mathrm{NMR}\left(\mathrm{C}_{6} \mathrm{D}_{6}, 20^{\circ} \mathrm{C}\right)$ : $50.94 \mathrm{ppm}$. MS (FAB) $m / z: 530\left(\mathrm{M}^{+},{ }^{52} \mathrm{Cr}\right), 530-28 n$ $(n=1-3)$.

\subsection{Synthesis of $\mathrm{fac}-\mathrm{Mo}(\mathrm{CO})_{3}\left(\eta^{3}-\mathrm{PNN}\right)$}

$\mathrm{Mo}(\mathrm{CO})_{6}(100 \mathrm{mg}, 0.37 \mathrm{mmol})$ and acetonitrile $(15$ $\mathrm{ml})$ were refluxed under dinitrogen for $12 \mathrm{~h}$ to produce $\mathrm{Mo}(\mathrm{CO})_{3}(\mathrm{NCMe})_{3}$. The reaction of $\mathrm{Mo}(\mathrm{CO})_{3}(\mathrm{NCMe})_{3}$ and PNN (150 mg, $0.37 \mathrm{mmol}$ ) was then carried out and worked up in a fashion identical with that above. fac-Mo(CO) $)_{3}\left(\eta^{3}-\mathrm{PNN}\right)(149 \mathrm{mg}, 0.26 \mathrm{mmol}, 70 \%)$ was obtained as dark red crystals after crystallization from dichloromethane-hexane. IR $\left(\mathrm{CH}_{2} \mathrm{Cl}_{2}, v_{\mathrm{CO}}\right): 1920 \mathrm{~s}$, $1816 \mathrm{~s}, 1794 \mathrm{~s} \mathrm{~cm}^{-1} .{ }^{1} \mathrm{H}-\mathrm{NMR}\left(\mathrm{C}_{6} \mathrm{D}_{6}, 20^{\circ} \mathrm{C}\right): 9.40$ (d, $\mathrm{CH}=\mathrm{N}), 8.05-5.95(\mathrm{~m}, \mathrm{Ph}, \mathrm{Py}), 4.08(\mathrm{~m}, 1 \mathrm{H}), 2,81$ (m, $1 \mathrm{H}), 2.12(\mathrm{~m}, 1 \mathrm{H}), 1.20\left(\mathrm{~m}, 1 \mathrm{H}, \mathrm{CH}_{2}\right) \mathrm{ppm} .{ }^{31} \mathrm{P}\left\{{ }^{1} \mathrm{H}\right\}-$ NMR $\left(\mathrm{C}_{6} \mathrm{D}_{6}, 20^{\circ} \mathrm{C}\right): 36.13 \mathrm{ppm}$. MS (FAB) $m / z: 574$ $\left(\mathrm{M}^{+},{ }^{96} \mathrm{Mo}\right), 574-28 n(n=1-3)$. Anal. Found $\mathrm{C}, 55.53$; $\mathrm{H}, 3.65 ; \mathrm{N}, 4.25 . \mathrm{C}_{30} \mathrm{H}_{25} \mathrm{Cl}_{2} \mathrm{~N}_{2} \mathrm{O}_{3} \mathrm{PMo}$ (containing a $\mathrm{CH}_{2} \mathrm{Cl}_{2}$ crystal solvent) Anal. Calc. C, 54.64; H, 3.82; $4.24 \%$.

\subsection{Synthesis of $\mathrm{fac}-W(\mathrm{CO})_{3}\left(\eta^{3}-\mathrm{PNN}\right)$}

$\mathrm{W}(\mathrm{CO})_{6}(90 \mathrm{mg}, 0.25 \mathrm{mmol})$ and acetonitrile $(20 \mathrm{ml})$ were refluxed under dinitrogen for $72 \mathrm{~h}$ to produce $\mathrm{W}(\mathrm{CO})_{3}(\mathrm{NCMe})_{3}$. The reaction of $\mathrm{W}(\mathrm{CO})_{3}(\mathrm{NCMe})_{3}$ and PNN (101 mg, $0.25 \mathrm{mmol}$ ) was then carried out and worked up in a fashion identical with that above. fac-W(CO) $)_{3}\left(\eta^{3}-\mathrm{PNN}\right)(119 \mathrm{mg}, 0.18 \mathrm{mmol}, 72 \%)$ was obtained as dark red crystals after crystallization from dichloromethane-hexane. IR $\left(\mathrm{CH}_{2} \mathrm{Cl}_{2}, v_{\mathrm{CO}}\right): 1912 \mathrm{~s}$, $1808 \mathrm{~s}, 1786 \mathrm{~s} \mathrm{~cm}^{-1} .{ }^{1} \mathrm{H}-\mathrm{NMR}\left(\mathrm{C}_{6} \mathrm{D}_{6}, 20^{\circ} \mathrm{C}\right): 9.45$ (d, $\mathrm{CH}=\mathrm{N}), 8.07-5.92(\mathrm{~m}, \mathrm{Ph}, \mathrm{Py}), 4.03(\mathrm{~m}, 1 \mathrm{H}), 3.93(\mathrm{~m}$, $1 \mathrm{H}), 2.89(\mathrm{~m}, 1 \mathrm{H}), 1.20\left(\mathrm{~m}, 1 \mathrm{H}, \mathrm{CH}_{2}\right) \mathrm{ppm} .{ }^{31} \mathrm{P}\left\{{ }^{1} \mathrm{H}\right\}-$ NMR $\left(\mathrm{C}_{6} \mathrm{D}_{6}, 20^{\circ} \mathrm{C}\right): 31.73$ (s, with ${ }^{183} \mathrm{~W}$ satellites, $\left.J_{\mathrm{W}-\mathrm{P}}=227 \mathrm{~Hz}\right)$ ppm. MS (FAB) $m / z: 662\left(\mathrm{M}^{+},{ }^{184} \mathrm{~W}\right)$, 662-28n $(n=1-3)$. Anal. Found $\mathrm{C}, 47.96 ; \mathrm{H}, 3.54 ; \mathrm{N}$, 3.75. $\mathrm{C}_{30} \mathrm{H}_{25} \mathrm{Cl}_{2} \mathrm{~N}_{2} \mathrm{O}_{3} \mathrm{PW}$ (containing a $\mathrm{CH}_{2} \mathrm{Cl}_{2}$ crystal solvent) Anal. Calc. C, 48.19; H, 3.34; 3.74\%.

\subsection{Synthesis of $\mathrm{W}(\mathrm{CO})_{4}\left(\eta^{2}-\mathrm{PNN}\right)$}

$\mathrm{W}(\mathrm{CO})_{6}(100 \mathrm{mg}, 0.28 \mathrm{mmol})$ and dichloromethane $(5 \mathrm{ml})$ were placed in a $50 \mathrm{ml}$ Schlenk flask under dinitrogen. A solution of $\mathrm{Me}_{3} \mathrm{NO}(45 \mathrm{mg}, 0.60 \mathrm{mmol})$ in acetonitrile $(7 \mathrm{ml})$ was added dropwise into the flask by a syringe over a period of $20 \mathrm{~min}$. The mixture was stirred at ambient temperature for $2 \mathrm{~h}$, at which point the IR spectrum indicated the presence of $\mathrm{W}(\mathrm{CO})_{4^{-}}$ $(\mathrm{NCMe})_{2}$. The acetonitrile solvent was then removed under vacuum. A solution of PNN (112 mg, 0.28 mmol) in dichloromethane $(7 \mathrm{ml})$ was added to the flask by a syringe and the reaction mixture was stirred at ambient temperature for $1 \mathrm{~h}$, resulting a solution color change from bright yellow to orange red. The volatile materials were removed under vacuum, and the residue was crystallized from dichloromethane-hexane to afford orange red crystals of $\mathrm{W}(\mathrm{CO})_{4}\left(\eta^{2}-\mathrm{PNN}\right)(99$ $\mathrm{mg}, 0.14 \mathrm{mmol}, 50 \%)$. IR $\left(\mathrm{CH}_{2} \mathrm{Cl}_{2}, v_{\mathrm{CO}}\right): 2008 \mathrm{~s}, 1894 \mathrm{~s}$, $1856 \mathrm{~s} \mathrm{~cm}^{-1} .{ }^{1} \mathrm{H}-\mathrm{NMR}\left(\mathrm{C}_{6} \mathrm{D}_{6}, 20^{\circ} \mathrm{C}\right): 8.52(\mathrm{~d}, \mathrm{CH}=\mathrm{N})$, 8.07-6.85 (m, Ph, Py), 4.35 (t, 2H, $\left.\mathrm{CH}_{2}\right), 3.11$ (t, 2H, $\left.\mathrm{CH}_{2}\right)$ ppm. ${ }^{31} \mathrm{P}\left\{{ }^{1} \mathrm{H}\right\}-\mathrm{NMR}\left(\mathrm{C}_{6} \mathrm{D}_{6}, 20^{\circ} \mathrm{C}\right): 24.19$ (s, with ${ }^{183} \mathrm{~W}$ satellites, $\left.J_{\mathrm{W}-\mathrm{P}}=238 \mathrm{~Hz}\right) \mathrm{ppm}$. MS $(\mathrm{FAB}) \mathrm{m} / z$ : $690\left(\mathrm{M}^{+},{ }^{184} \mathrm{~W}\right), 690-28 n(n=1-4)$. Anal. Found C, 52.12; H, 3.44; N, 4.00. $\mathrm{C}_{30} \mathrm{H}_{23} \mathrm{~N}_{2} \mathrm{O}_{4} \mathrm{PW}$; Anal. Calc. C, $52.19 ; \mathrm{H}, 3.35 ; 4.05 \%$.

\subsection{Thermolysis of $\mathrm{W}(\mathrm{CO})_{4}\left(\eta^{2}-\mathrm{PNN}\right)$}

A solution of $\mathrm{W}(\mathrm{CO})_{4}\left(\eta^{2}\right.$-PNN) $(9 \mathrm{mg})$ in $n$-octane $(4 \mathrm{ml})$ was heated to reflux under dinitrogen for $2 \mathrm{~h}$, resulting in a solution color change from orange red to deep red. The octane solvent was removed under vacuum, and the residue crystallized from dichloromethane-hexane to yield $\mathrm{fac}-\mathrm{W}(\mathrm{CO})_{3}\left(\eta^{3}-\mathrm{PNN}\right)(6 \mathrm{mg})$.

Similar results were obtained by heating $\mathrm{W}(\mathrm{CO})_{4}\left(\eta^{2}-\right.$ $\mathrm{PNN}$ ) in the presence of PNN ligand. There was no evidence for the formation of $\mathrm{W}(\mathrm{CO})_{3}(\mathrm{PNN})_{2}$ or $\mathrm{W}(\mathrm{CO})_{4}(\mathrm{PNN})_{2}$.

\subsection{Attempts to isomerize fac-W(CO $)_{3}\left(\eta^{3}-P N N\right)$ to mer- $W(\mathrm{CO})_{3}\left(\eta^{3}-\mathrm{PNN}\right)$ thermally}

A solution of $f a c-\mathrm{W}(\mathrm{CO})_{3}\left(\eta^{3}-\mathrm{PNN}\right)(5 \mathrm{mg})$ in toluene solvent $(3 \mathrm{ml})$ was heated to reflux under dinitrogen for $12 \mathrm{~h}$. The reaction monitored by IR showed no new CO absorptions to indicate the formation of mer$\mathrm{W}(\mathrm{CO})_{3}\left(\eta^{3}-\mathrm{PNN}\right)$.

\subsection{Co-pyrolysis of $W(C O)_{6}$ and $P N N$ in a sealed tube}

$\mathrm{W}(\mathrm{CO})_{6}(23 \mathrm{mg})$ and $\mathrm{PNN}(21 \mathrm{mg})$ were mixed, ground, and sealed in a Pyrex glass tube under vacuum ( 0.01 torr). The tube was placed in a silicon oil bath at $125^{\circ} \mathrm{C}$ for $1 \mathrm{~h}$, removed from oil bath and cooled to ambient temperature, and opened in air. The products were extracted with dichloromethane and crystallized by adding $n$-hexane. $f a c-\mathrm{W}(\mathrm{CO})_{3}\left(\eta^{3}\right.$-PNN) $(10 \%)$ and $\mathrm{W}(\mathrm{CO})_{4}\left(\eta^{2}-\mathrm{PNN}\right)(23 \%)$ were obtained.

\subsection{Structural determination for fac- $W(\mathrm{CO})_{3}\left(\eta^{3}-P N N\right)$, fac-Mo $(\mathrm{CO})_{3}\left(\eta^{3}-\mathrm{PNN}\right)$ and $\mathrm{W}(\mathrm{CO})_{4}\left(\eta^{2}-\mathrm{PNN}\right)$}

Crystals of $\mathrm{fac}-\mathrm{W}(\mathrm{CO})_{3}\left(\eta^{3}-\mathrm{PNN}\right)($ ca. $0.60 \times 0.50 \times$ $\left.0.20 \mathrm{~mm}^{3}\right), \quad f a c-\mathrm{Mo}(\mathrm{CO})_{3}\left(\eta^{3}-\mathrm{PNN}\right) \quad$ (ca. $0.50 \times 0.40 \times$ 
Table 3

Crystal data and refinement details for $\mathrm{W}(\mathrm{CO})_{4}\left(\eta^{2}-\mathrm{PNN}\right), f a c-\mathrm{W}(\mathrm{CO})_{3}\left(\eta^{3}-\right.$ $\mathrm{PNN})$ and $f a c-\mathrm{Mo}(\mathrm{CO})_{3}\left(\eta^{3}-\mathrm{PNN}\right)$

\begin{tabular}{|c|c|c|c|}
\hline & $\begin{array}{l}\mathrm{W}(\mathrm{CO})_{4^{-}} \\
\left(\eta^{2}-\mathrm{PNN}\right)\end{array}$ & $\begin{array}{l}\mathrm{W}(\mathrm{CO})_{3^{-}} \\
\left(\eta^{3}-\mathrm{PNN}\right)\end{array}$ & $\begin{array}{l}\mathrm{Mo}(\mathrm{CO})_{3^{-}} \\
\left(\eta^{3}-\mathrm{PNN}\right)\end{array}$ \\
\hline Formula & $\mathrm{C}_{30} \mathrm{H}_{23} \mathrm{~N}_{2} \mathrm{O}_{4} \mathrm{PW}$ & $\mathrm{C}_{29} \mathrm{H}_{23} \mathrm{~N}_{2} \mathrm{O}_{3} \mathrm{PW}$ & $\mathrm{C}_{29} \mathrm{H}_{23} \mathrm{~N}_{2} \mathrm{O}_{3} \mathrm{PMo}$ \\
\hline Crystal solvent & & $\mathrm{CH}_{2} \mathrm{Cl}_{2}$ & $\mathrm{CH}_{2} \mathrm{Cl}_{2}$ \\
\hline Formula weight & 690.32 & 747.24 & 659.33 \\
\hline Temperature (K) & $293(2)$ & $293(2)$ & 293(3) \\
\hline Radiation $\lambda(\AA)$ & 0.71073 & 0.71073 & 0.71073 \\
\hline Crystal system & Triclinic & Monoclinic & Monoclinic \\
\hline Space group & $P \overline{1}$ & $P 2_{1} / n$ & $P 2_{1} / n$ \\
\hline \multicolumn{4}{|l|}{ Unit cell dimensions } \\
\hline$a(\AA)$ & $8.789(2)$ & $13.400(2)$ & $13.478(3)$ \\
\hline$b(\AA)$ & $10.533(2)$ & $16.364(2)$ & $16.390(4)$ \\
\hline$c(\AA)$ & $15.991(3)$ & $13.602(2)$ & $13.611(3)$ \\
\hline$\alpha\left({ }^{\circ}\right)$ & $80.58(2)$ & 90 & 90 \\
\hline$\beta\left(^{\circ}\right)$ & $86.52(2)$ & $102.02(1)$ & $102.34(2)$ \\
\hline$\gamma\left({ }^{\circ}\right)$ & $68.73(2)$ & 90 & 90 \\
\hline$V\left(\AA^{3}\right)$ & $1361.0(5)$ & $2917.3(6)$ & $2937(1)$ \\
\hline$Z$ & 2 & 4 & 4 \\
\hline$D_{\text {calc. }}\left(\mathrm{g} \mathrm{cm}^{-3}\right)$ & 1.685 & 1.701 & 1.491 \\
\hline$F(000)$ & 676 & 1464 & 1336 \\
\hline$\mu\left(\mathrm{mm}^{-1}\right)$ & 4.341 & 4.232 & 0.717 \\
\hline$R_{1} / w R_{2}{ }^{a}$ & $0.0197 / 0.0477$ & $0.0290 / 0.0759$ & $0.0421 / 0.1079$ \\
\hline $\begin{array}{l}\text { Goodness-of- } \\
\text { fit on } F^{2}\end{array}$ & 1.062 & 1.077 & 1.053 \\
\hline
\end{tabular}

$\left.{ }^{\mathrm{a}} R_{1}=\Sigma|| F_{\mathrm{o}}|-| F_{\mathrm{c}}|/ \Sigma| F_{\mathrm{o}} \mid ; w R_{2}=\left\{\Sigma\left[w\left(\left|F_{\mathrm{o}}\right|^{2}-\left|F_{\mathrm{c}}\right|^{2}\right)^{2}\right] / \Sigma w\left|F_{\mathrm{o}}\right|^{4}\right]\right\}^{1 / 2}$.

$\left.0.20 \mathrm{~mm}^{3}\right)$ and $\mathrm{W}(\mathrm{CO})_{4}\left(\eta^{2}-\mathrm{PNN}\right)(\mathrm{ca} .0 .60 \times 0.50 \times$ $0.50 \mathrm{~mm}^{3}$ ) were each mounted in a thin-walled glass capillary and aligned on the Nonius CAD-4 diffractometer with graphite-monochromated $\mathrm{Mo}-\mathrm{K}_{\alpha}$ radiation $(\lambda=0.71073 \AA)$. The data were collected using the $\theta / 2 \theta$ scan technique with $\theta$ ranging from 1.94 to $25.00^{\circ}$ for $f a c-\mathrm{W}(\mathrm{CO})_{3}\left(\eta^{3}-\mathrm{PNN}\right), \quad 1.93$ to $25.00^{\circ}$ for $\mathrm{fac}$ $\mathrm{Mo}(\mathrm{CO})_{3}\left(\eta^{3}-\mathrm{PNN}\right)$ and 1.29 to $25.00^{\circ}$ for $\mathrm{W}(\mathrm{CO})_{4}\left(\eta^{2}\right.$ $\mathrm{PNN})$. All data were corrected for Lorentz and polarization effects and for the effects of absorption. The structures were solved by the heavy-atom method and refined by full-matrix least-square cycles on $F^{2}$ on the basis of 4232 observed reflections $[I>2 \sigma(I)]$ for fac-W(CO) $)_{3}\left(\eta^{3}-\mathrm{PNN}\right), 3612$ observed reflections for fac- $\mathrm{Mo}(\mathrm{CO})_{3}\left(\eta^{3}-\mathrm{PNN}\right)$ and 4438 observed reflections for $\mathrm{W}(\mathrm{CO})_{4}\left(\eta^{2}-\mathrm{PNN}\right)$. The non-hydrogen atoms were refined anisotropically. Hydrogen atoms were included but not refined. All calculations were performed using the SHELXTL package. A summary of relevant crystallographic data is provided in Table 3.

\section{Supplementary materials}

Crystallographic data for the structural analysis has been deposited with the Cambridge Crystallographic Data Centre, CCDC nos. 136819 for $\mathrm{W}(\mathrm{CO})_{4}\left(\eta^{2}\right.$ $\mathrm{PNN}), 136817$ for $\mathrm{fac}-\mathrm{W}(\mathrm{CO})_{3}\left(\eta^{3}-\mathrm{PNN}\right)$ and 136818 for $f a c-\mathrm{Mo}(\mathrm{CO})_{3}\left(\eta^{3}-\mathrm{PNN}\right)$. Copies of this information may be obtained free of charge from: The Director, CCDC, 12 Union Road, Cambridge, CB2 1EZ, UK (Fax: + 44-1223-336033; e-mail: deposit@ccdc.cam. ac.uk or www: http://www.ccdc.cam.ac.uk).

\section{Acknowledgements}

We are grateful for support of this work by the National Science Council of Taiwan.

\section{References}

[1] A. Lavery, S.M. Nelson, J. Chem. Soc. Dalton Trans. (1984) 615.

[2] E. Drent, J.A.M. van Broekhoven, M.J. Doyle, J. Organomet. Chem. 417 (1991) 235.

[3] B.M. Trost, T.R. Verhoeven, J. Am. Chem. Soc. 100 (1978) 3435.

[4] G.W. Parshall, S.D. Ittel, Homogeneous Catalysis, Wiley, New York, 1992.

[5] F. Benvenuti, C. Carlini, M. Marchionna, R. Patrini, A.M. Raspolli Galletti, G. Sbrana, J. Mol. Catal. A Chem. 140 (1999) 139.

[6] R.E. Rülke, V.E. Kaasjager, P. Wehman, C.J. Elsevier, P.W.N.M. van Leeuwen, K. Vrieze, J. Fraanje, K. Goubitz, A.L. Spek, Organometallics 15 (1996) 3022.

[7] W.-Y. Yeh, C.-C. Yang, S.-M. Peng, G.-H. Lee, unpublished results.

[8] P. Wehman, R.E. Rülke, V.E. Kaasjager, P.C.J. Kamer, H. Kooijman, A.L. Spek, C.J. Elsevier, K. Vrieze, P.W.N.M. van Leeuwen, J. Chem. Soc. Chem. Commun. (1995) 331.

[9] T.B. Rauchfuss, J. Organomet. Chem. 162 (1978) C19.

[10] F.A. Cotton, G. Wilkinson, Advanced Inorganic Chemistry, fifth ed., Wiley, New York, 1988.

[11] F. Basolo, Polyhedron 9 (1990) 1503.

[12] D.M.P. Mingos, J. Organomet. Chem. 179 (1979) C29.

[13] S.C.N. Hsu, W.-Y. Yeh, J. Chem. Soc. Dalton Trans. (1998) 125.

[14] P.E. Garrou, Chem. Rev. 81 (1981) 229.

[15] D.F. Shriver, M.A. Drezdzon, The Manipulation of Air-Sensitive Compounds, second ed., Wiley, New York, 1986.

[16] D.D. Perrin, W.L. Armarego, D.R. Perrin, Purification of Laboratory Chemicals, Pergamon, Oxford, 1966. 